\title{
Europe is it ready for Free Movement of its Workforce?
}

\author{
Dr David Floyd ${ }^{1}$ and Dr J ohn McManus \\ Lincoln Business School, University of Lincoln, United Kingdom
}

\begin{abstract}
Purpose - To examine what could be achieved through workforce mobility in Europe.

Design/methodology/approach - Literature and case review

Findings - Findings indicate that full mobility of a European workforce is largely permitted and tolerated though a complex web of legal policy and constraints which need to be reviewed if full mobility is to be achieved within the EU.
\end{abstract}

Practical implications - The paper draws on integration and trade theory to highlight the issues of mobility within the EU. The paper may prove useful to policy makers and researchers.

Originality / value - This paper allows researchers to gain an understanding of the issues in workforce mobility within the EU and build a conceptual portrait of the challenges faced by policy makers.

Key words Europe, Workforce, Policy, Workforce, Citizens, EU, Capital Paper type View point

\footnotetext{
${ }^{1}$ Corresponding author dfloyd@lincoln.ac.uk
} 


\section{Introduction}

There are numerous economic benefits with the free movement of labour. Firstly this can help skill shortages in key industries, (Floyd, 1997), (McManus, 2009). Polish workers for example have helped lower the cost of builders and plumbers in the UK for the use of their services. There are also multiplier effects since workers will spend money locally and will contribute to taxation. Workers will also use transport and accommodation services as well as buying their provisions locally. Skill may also be past on to others as an external benefit created. Establishing a free market will also lead to less protectionism thereby helping to reduce cost and widen the choice of available suppliers. Free labour markets can also result in less protectionist pressure, this helps expand trade and achieve a higher global growth. Indeed the recent response to the global crisis has been to avoid going down a protectionist route. Krugman shows the benefits arising from comparative advantage when more international trade takes place. There can also be other benefits arising from new businesses that start to evolve supporting new cultures in the community (Krugman, 1987).

\section{Overcoming EU barriers}

There are a number of cases where free mobility has been questioned across Europe despite the fact free mobility has been offered in theory. For example, Niemann 2008 shows that foreign workers with high skills that have been offered work permits in one EU member country are not permitted to work in other EU member states. This undermines the concept of EU citizenship since there are limited rights associated with it. In a similar way Guliyeva shows in the past that EU nationals are not entitled to student grants in other EU member states unless they have lived there for at least five years in many cases (Guliyeva, 2008). Some of the best skills can therefore not be developed due to this situation and the EU may lose out from this. The EU provides funds for a lucky small number of people. There has also been recent concern that citizens from recently joined member states have not been given full mobility rights. In the case of the UK workers from EU 25 member countries have been allowed to work in the 
UK, however benefits could not be clamed for 2 years for the Eastern European accession members. Bulgaria and Romanians can only work in Britain in specific industries though they will be given full rights by 2014 . France and Germany had different policies and issued a quota system on Eastern European workers. These complex arrangements make it difficult to achieve the benefits of migration and this particularly influences the skills gap that exists in many countries. Such issues also become more difficult when one sees a different approach also being adopted by member states to workers from outside the European Union (McManus, 2009). It has been shown that in the UK non EU workers represent the largest number of foreign workers at present. Again there is a need for foreign workers and an effective EU policy being adopted. The EU has introduced the professions directive as well as the harmonisation of qualifications though there are still disparities between countries as the training period for various professions differs amongst countries and some countries may show a bias towards home country educated workers.

There are also strange differences regarding EU member state provision for healthcare. Citizens of the UK who have gone abroad are not allowed to use the national health care services if they return to the UK for a period of six months. Indeed trying to have an EU wide health service has proved to be very difficult. In France for example healthcare has to be paid for though around eighty per cent of the total costs can be claimed back. In some countries such as the UK care may not be provided for EU citizens if it is not available for example there have been recent problems of shortages of dentists. The EU agreements on health provision therefore vary a great deal and this may prove to be a barrier for encouraging the benefits of migration.

\section{Governance across EU member states}

It could be argued that European law has evolved in an experimental way in that the EU has tried to devise methods of keeping all countries on board. For example, the clause of subsidiary has been introduced to try and allow the local decision making process take place at the country level where possible. Countries have been allowed to opt out of policies such as the UKS 
approach to the working time directive. The EU has also introduced a qualified maj ority voting process for most directives where countries are given votes depending on their population size. The system is far from a perfect solution but allows a great deal of progress on integration to take place, (Dearden, 2005). There have been suggestions of a democratic deficit though it is also important to remember that Europe has become the most integrated trading bloc in the world partly due to having effective legal processes in place. There has also been the introduction of the social chapter which gives workers minimum standards in EU member states. EU states vary a great deal in terms of social protection and the social chapter does not introduce any numerical measures for member states to comply with, (Mercado, 2001). The EU also provides funds to encourage mobility and integration though the EU only has a limited number of resources. Those with the best knowledge of the schemes tend to get the most equal treatment across Europe and these have tended to be the people with the best access to education and resources. It is suggested by Velluti that it is often the educated middle class who are in a position to take advantage of these schemes. Due to the limitation of resources there is increasing reliance on soft law in this field leaving it up to individuals to take action (Velluti, 2009).

Labour mobility is also a new area for EU law since focus in Treaties such as Maastricht and Amsterdam was more on the completion of a single market for goods and services with the main goal of expanding trade. There has also been a variation on social policy across member states (Floyd, 1997). The Scandinavian countries for example have offered greater social protection than Anglo-Saxon countries such as the UK. Often taxes have been higher in the Scandinavian countries though investment in training and education has been prioritised more in France Germany and Scandinavia compared with the UK. Workers also have achieved higher levels of payment in the case of redundancy for example. This may have an impact on the decision whether to work abroad. Other mobility constraints may include different levels of health care and the problems of having to re register for work when moving to a new town in countries like France and Germany. There are additional 
problems to mobility including family and possible discrimination (Granovetter, 2009).

\section{Future possibilities}

Increasingly the European Union is being seen as an integrated education market, for example it is possible to study in one EU country in many European languages then continues at a higher level in another EU Country thanks to the Bologna process. According to the UK Guardian newspaper numbers of international students at German universities are set to rise from 1.8 million to 7.2 million from 2000 to 2025 . Increasingly more information is being provided to workers on job placement in the EU, the increasing speed of technology and the mobile phone are also helping. Globalisation forces are further expanding the pace of change. However there are still fewer than 5\% of EU workers willing to work abroad though this has increased slightly over the last few years (Mayes, 2007). It is unlikely that we will have a mobile labour force like the USA with over $20 \%$ of people willing to move; this highlights the importance of historical and cultural barriers that still exist in the EU as has been considered in this paper.

\section{Concluding remarks}

Clearly, there are numerous barriers to be overcome prior to seeing the full functioning of a mobile European workforce. Capital and labour movement theory shows that in some cases workers will not move from country to country unless a sufficient income is provided (Mayes, 2008 \& McManus, 2009). This helps to explain why many Polish workers have moved to the UK in the past as well as workers from former UK colonies. There tends to be more mobility between countries where there is less distance to travel (Read, 1991). Full mobility is the full functioning of a mobile European workforce. If full mobility is to be permitted legal constraints will need to be lifted. This will prove difficult due to the way the legal process has developed historically in the EU. It is argued that the variations in the social provisions provided in EU member States, will prevent full mobility. There 
are other barriers to mobility including lack of information on job opportunities as well as other social and cultural barriers including language barriers and problems of uprooting and selling properties. The factors considered above and the legal process surrounding these issues help to understand and explain why it is likely to be a generation before there is a full functioning mobile labour force across Europe. 


\section{References}

Dearden S., (2005), European Economic Integration, FT Publications

Floyd D., (1997), The European Social Chapter, J ournal of European Business Education, Vol 6, No2

Granovetter M., (2001), The Sociology of Economic Life, $2^{\text {nd }}$ Edition, West view Press, USA

Guliyeva G., (2008), Lost in Transition, European Law Review, Vol 33, No6 Krugman P., (1987), International Economics, Scott

Mayes D. , (2007), Factor Mobility, Ch. 8 in El-Agraa, A European Union, Publication, Cambridge, UK

McManus, J., White, D., Botten, N., (2009), Managing Global Business Strategies: A 21st Century Perspective, Chandos Publishing Oxford, UK

Niemann A., (2008), Immigration Policy Treaty Revision, J ournal of Common Market Studies, Vol 46, No3

Read R., (1991), Does labour mobility matter? European Business Review, Vol 91, No2

Guardian newspaper, (2009), Education supplement, EU Countries respond to international students, $31^{\text {st }}$ March

Velluti S., (2009), New Governance and the European Strategy for Employment, Routledge Publication, UK 